\title{
PENGARUH PEMBERIAN SILIKA TERHADAP HASIL TANAMAN OKRA
}

\author{
Eko Apriliyanto*, Sarno \\ Program Studi Agroteknologi, Politeknik Banjarnegara, \\ Jl. Raya Madukara Km. 2 Kenteng, Banjarnegara, 53463 \\ *E-mail: okeapriliyanto@gmail.com
}

\begin{abstract}
ABSTRAK
Okra (Abelmoschus esculentus L.) merupakan salah satu komoditi hortikultura yang memiliki nilai ekonomi tinggi. Kebuatuhan akan okra saat ini masih tinggi, tetapi belum diiringi dengan peningkatan hasil produksinya. Peningkatan kandungan silika dan lignin pada organ tanaman terkait dengan komponen dinding sel yang memberikan kekuatan fisik, sehingga tanaman tetap tegak, tidak roboh meskipun mengalami cekaman genangan maupun kekeringan. Penelitian ini bertujuan untuk mengetahui pengaruh pemberian silika terhadap hasil tanaman okra. Rancangan yang digunakan dalam penelitian adalah rancangan acak kelompok lengkap (RAKL). Perlakuan yang dicobakan yaitu 4 konsentrasi pemberian silika (Tenaz $\mathrm{SiO}_{2} 1,3 \%$, Mo 10 ppm, Co 5 ppm, N 2,8\%, dan $\mathrm{K}_{2} \mathrm{O}$ $0,6 \%$ ). Perlakuan yang diberikan yaitu tanpa pemberian silika (S0), silika $1 \%$ (S1), silika 2\% (S2), dan silika 3\% (S3). Penelitian dilaksanakan bulan Maret hingga Oktober 2018 di kelurahan Kenteng, Madukara, Banjarnegara dengan jenis tanah latosol. Intensitas serangan hama kutu daun pada S0, S1, S2, dan S3 berturut-turut 1,43\%, 5,71\%, 9,29\%, dan 3,57\%. Intensitas serangan hama ulat pada S0, S1, S2, dan S3 berturut-turut 0,00\%, $9,29 \%, 0,00 \%$, dan $4,64 \%$. Intensitas serangan hama wereng daun tertinggi pada perlakuan S0 yaitu $16,07 \%$, terendah pada perlakuan S1 dan S2 yaitu 0,00\%, sedangkan perlakuan S3 yaitu $8,57 \%$. Pemberian silika pada tanaman okra belum mampu meningkatkan tinggi tanaman, jumlah buah, bobot buah, dan bobot segar tanaman.
\end{abstract}

Kata kunci: hama, hasil, okra, serangan, silika

\begin{abstract}
Okra (Abelmoschus esculentus L.) is one of the horticultural commodities which has high economic value. The requirment of okra is high nowdays, but this situation has not been followed by the raising of okra's production. The increase of silica and lignin's content in plant organs is related to the component of cell walls wich give physical strength, so that the plantare settled, do not collapse despite although experiencing stagnant inundation dryness. This research's aim is to determine the effect of giving silica to the yield of okra. The design used in the research was a randomized completely block design (RCBD). The treatments tested were 4 concentrations of silica (Tenaz $\mathrm{SiO}_{2} 1.3 \%$, Mo $10 \mathrm{ppm}$, Co 5 ppm, $\mathrm{N} 2.8 \%$, and $\mathrm{K}_{2} \mathrm{O} 0.6 \%$ ). The treatment given was without silica giving (SO), silica $1 \%$ (S1), silica 2\% (S2), and silica 3\% (S3). The research was conducted from March to October 2018 in Kenteng, Madukara, Banjarnegara with latosol soil type. The intensity of aphids on SO, S1, S2, and S3 were 1.43\%, 5.71\%, 9.29\% and 3.57\%. The intensity of caterpillar pest attacks on SO, S1, S2, and S3 in succession were 0.00\%, 9.29\%, 0.00\%,
\end{abstract}


and $4.64 \%$. The highest intensity of leaf leafhoppers attack on treatment SO is $16.07 \%$, the lowest were treatment S1 and S2 which was $0.00 \%$, while treatment S3 was $8.57 \%$. Silica giving toward okra plants has not been able to increase plant height, number of fruits, fruit weight, and fresh weight of plants.

Keywords: attack, okra, pest, silica, yield

\section{PENDAHULUAN}

Okra (Abelmoschus esculentus L.) merupakan salah satu komoditi hortikultura yang memiliki nilai ekonomi tinggi. Kebutuhan akan okra saat ini masih tinggi, tetapi belum diiringi dengan peningkatan hasil produksinya. Di Indonesia okra masing jarang dibudidayakan dalam areal luas, sebagian besar masih dikelola berdasarkan permintaan pasar. Beberapa usahatani okra di Indonesia biasanya menanam okra berdasarkan kerjasama, baik dalam negeri maupun luar negeri. Okra di Indonesia masih digunakan sebatas sebagai sayur, pemanfaatan untuk industri belum dilakukan secara optimum. Beberapa negara di Asia telah memanfaatan okra untuk kepentingan industri. Biswas et al., (2016), okra selain penting untuk nutrisi dan kesehatan, juga memiliki peran penting dalam penghasilan dan subsisten pendapatan pada petani pedesaan India

Salah satu kendala dalam budidaya okra adalah adanya serangan organisme pengganggu tumbuhan (OPT). OPT yang menyerang okra dapat berupa hama dan patogen. Serangan hama dapat menurunkan kualitas dan kuantitas hasil okra, selain itu serangan pada bagian daun juga dapat menurunkan hasil baik kualitas dan kuantitas hasil secara tidak langsung. Upaya pengendalian hama yang banyak dilakukan saat ini menggunakan insektisida kimia sintetis. Padahal masih ada upaya lain yang ramah lingkungan untuk mengurangi serangan hama tersebut. Upaya peningkatan ketahanan tanaman dapat digunakan sebagai alternatif pengendalian hama okra. Selain ramah lingkungan, upaya ini juga mudah disinergikan dengan metode pengendalian lainnya.

Upaya peningkatan hasil okra dapat melalui pemberian pupuk yang tepat. Penggunaan unsur hara baik berupa pupuk organik, pupuk kimia sintetis, atau bahan kimia lain yang diberikan secara optimum, dapat meningkatkan hasil tanaman. Hasil penelitian Adil et al., (2016) pada tanaman tomat dan okra yang ditanam berturutan terlihat bahwa bobot buah segar tomat yang ditanam pertama sebelum okra, dipengaruhi secara nyata oleh pemberian kompos baik yang berasal dari pemotongan sapi maupun dari kotoran ayam. Pemberian kompos menaikkan bobot buah segar secara nyata. Pemberian urea sebanyak 5 g N/pot menyebabkan tanaman tidak tumbuh akibat kandungan $\mathrm{N}$ terlalu tinggi. Salah satu unsur mikro yang dibutuhkan oleh tanaman dalam jumlah yang cukup banyak adalah silika ( $\mathrm{Si}$ ) (Puteri et al., 2014).

Pemupukan lewat daun maupun akar sebagai salah satu usaha intensifikasi pertanian merupakan usaha yang bertujuan menambah persediaan unsur hara dibutuhkan tanaman untuk meningkatkan produksi dan mutu hasil tanaman. Unsur hara $\mathrm{Si}$ bermanfaat dalam mendukung pertumbuhan tanaman yang sehat (Fitriani dan Haryanti, 2016). Dewi et al., (2014) dosis optimal $\mathrm{Si}$ yang mampu menginduksi ketahanan bibit kelapa sawit terhadap cekaman kekeringan berada pada kisaran 5,1-10,2 gram/bibit. Aplikasi Si pada bibit kelapa sawit mampu menginduksi ketahanannya terhadap cekaman kekeringan melalui mekanisme pengerasan, pemanjangan dan perluasan akar serta stomata yang tetap membuka lebih lebar. 
Kristanto (2018), pemupukan silika meningkatkan kandungan silika dan lignin organ tanaman. Peningkatan kandungan silika dan lignin pada organ tanaman terkait dengan komponen dinding sel yang memberikan kekuatan fisik, sehingga tanaman tetap tegak, tidak roboh meskipun mengalami cekaman genangan maupun kekeringan. Fitriani dan Haryanti, (2016) perlakuan pemupukan nanosilika dengan dosis berbeda berpengaruh terhadap tinggi tanaman, jumlah daun, panjang akar, namun tidak berpengaruh terhadap berat basah tanaman tomat (Solanun lycopersicon) var Bulat. Pupuk nanosilika $75 \%$ berpengaruh paling tinggi terhadap pertumbuhan tanaman tomat (Solanum lycopersicum) var. Bulat

Dilihat dari peranan Si secara tidak langsung dapat meningkatkan produksi tanaman, sehingga pemupukan $\mathrm{Si}$ sebenarnya diperlukan untuk pertumbuhan tanaman (Nurmala et al., 2016). Trisnaningsih dan Nasution (2015), kultivar padi yang berbeda-beda ketahannya terhadap patogen ini, hal ini tidak hanya dipegaruhi oleh gen ketahanan yang mengontrol yang dikandung oleh tanaman tersebut, banyak gen tahan (Poligenik) atau gen tunggal (monogenik) tapi dipengaruhi juga oleh ketebalan kutikula dan silika pada sel epidermis daun, ketahanan secara mekanis.

Penelitian Dewi et al., (2014), silika juga memiliki peran dalam menginduksi tanaman terhadap cekaman kekeringan. Dosis optimal $\mathrm{Si}$ yang mampu menginduksi ketahanan bibit kelapa sawit terhadap cekaman kekeringan adalah pada kisaran 5,1 -10,2 gram/bibit. Aplikasi Si pada bibit kelapa sawit mampu menginduksi ketahanannya terhadap cekaman kekeringan melalui mekanisme pengerasan, pemanjangan dan perluasan akar serta stomata yang tetap membuka lebih lebar.
Hama serangga adalah salah satu faktor paling membatasi peningkatan hasil okra (Biswas, 2016). Hama tanaman okra yaitu Podagrica uniformis Jac, Aphis gossypii Glov, Sylepta derogata (F.), Spodoptera litoralis Boisd, Prodenia litura (F.), Dysdercus superstitiosus (F.), D. cingulatus, Epilachna similis (F.), Bemisia tabaci (Genn.) dan Zonocerus variegatus (F.), Lagria villosa (F.), L. cuprina Thoms, Mylabris temporalis Wellni, $M$. trifasciata (Thumb.), Lapidognatha $\mathrm{sp}$ dan Empoasca devastans (D.) Xanthodes transversa, Anomis fulvida, Helicoverpa armigera, Earias vittella, Spilosoma obliqua, Nezara viridula, Myllocerus discolor, Ricania speculum, Mylabris pustulata, Cletus punctiger, Monolepta signata, Amrasca biguttula biguttula (Obeng-Ofori dan Sackey, 2003; Nair et al., 2017). Penelitian ini bertujuan untuk mengetahui pengaruh pemberian silika terhadap hasil tanaman okra.

\section{METODE}

Penelitian ini dilaksanakan bulan Maret hingga Oktober 2018 di lahan percobaan Program Studi Agroteknologi Politeknik Banjarnegara. Lahan percobaan berada di kelurahan Kenteng, kecamatan Madukara, kabupaten Banjarnegara dengan ketinggian tempat 323 mdpl (BPS Kab. Banjarnegara, 2017). Adapun jenis tanahnya adalah latosol (Permana et al., 2017).

Pelaksanaan budidaya okra yang dilakukan sebagai berikut:

a. Persemaian

Benih okra yang digunakan yaitu Okra F1 Carmine Splendor dengan media semai berupa tanah : pupuk kompos dengan perbandingan 2: 1 . Benih disemai pada bak semai selama 10 hari.

b. Media tanam

Media tanam berupa campuran tanah dan pupuk kotoran kambing dengan 
perbandingan $9,75 \mathrm{~kg}: 0,25 \mathrm{~kg}$ pada polibag berdiameter $30 \mathrm{~cm}$.

\section{c. Penanaman}

Bibit okra yang seragam dan sehat ditanam dengan jarak tanam $50 \times 50 \mathrm{~cm}$.

d. Pemeliharaan Tanaman

Pemeliharaan yang dilakukan yaitu penyiangan gulma, penyiraman, dan pemberian ajir.

Rancangan yang digunakan dalam penelitian adalah rancangan acak kelompok lengkap (RAKL). Penelitian dengan 4 perlakuan menggunakan 10 ulangan, sehingga terdapat 40 unit percobaan. Perlakuan yang dicobakan yaitu 4 konsentrasi pemberian silika (Tenaz $\mathrm{SiO}_{2}$ 1,3\%, Mo 10 ppm, Co 5 ppm, N 2,8\%, dan $\mathrm{K}_{2} \mathrm{O} 0,6 \%$ ) sebagai berikut:

$\begin{array}{ll}\text { S0 } & \text { : Kontrol (akuades) } \\ \text { S1 } & \text { : Silika 1\% } \\ \text { S2 } & \text { : Silika 2\% } \\ \text { S3 } & \text { : Silika 3\% }\end{array}$

Aplikasi silika diberikan pad 14 hari setelah tanam (hst) dengan cara melakukan penyemperotan ke seluruh bagian tanaman sesuai dengan perlakuan masing-masing.

Peubah yang diamati adalah intensitas serangan hama, komponen pertumbuhan dan hasil pada tanaman okra.

\section{a. Intensitas serangan hama}

Pengamatan intensitas serangan hama tanaman okra dilakukan pada 2 minggu (mst). Intensitas serangan hama dihitung dengan rumus Natawigena (1993) sebagai berikut:

$$
I S=\sum\left(\frac{n x v}{N x Z}\right) \times 100 \%
$$

Keterangan:

IS $=$ Intensitas serangan $(\%)$

$\mathrm{N}=\quad$ Jumlah bagian tanaman/tanaman yang diamati pada skala kerusakan tertentu
$\mathrm{V}=$ Skala kerusakan serangan oleh OPT pada Tabel 1.

$\mathrm{N}=$ Jumlah tanaman keseluruhan yang diamati

$Z=\quad$ Skala kerusakan tertinggi

Tabel 1. Kriteria kategori intensitas kerusakan

\begin{tabular}{ccc} 
Skala & Persentase & Kriteria \\
\hline 0 & 0 & Normal \\
1 & $0<\mathrm{x} \leq 25$ & Ringan \\
2 & $25<\mathrm{x} \leq 50$ & Sedang \\
3 & $50<\mathrm{x} \leq 75$ & Berat \\
4 & $\mathrm{x}>75$ & Sangat berat \\
\hline
\end{tabular}

b. Komponen Pertumbuhan dan Hasil Okra

Pengamatan komponen pertumbuhan berupa tinggi tanaman. Komponen hasil yang diamati berupa jumlah buah, bobot buah, dan bobot segar tanaman. Jumlah buah dan bobot buah diamati pada panen pertama dan kedua.

Analisis data menggunakan Uji F, apabila berbeda nyata dilanjutkan dengan DMRT (Duncan Multiple Range Test) pada taraf $5 \%$.

\section{HASIL DAN PEMBAHASAN}

Hasil analisis tinggi tanaman okra menunjukkan tidak berbeda nyata pada seluruh perlakuan (Gambar 1.). Tinggi tanaman pada S0, S1, S2, dan S3 berturut-turut $23,63 \mathrm{~cm} ; 22,71 \mathrm{~cm} ; 23,30$ $\mathrm{cm}$; dan 22,51 cm. Diduga pemberian silika pada tanaman okra belum mampu meningkatkan tinggi tanaman. Penelitian Sugiyanta et al., (2018) tentang pemberian silika cair pada tanaman padi menunjukkan bahwa aplikasi silika cair tidak memberikan pengaruh yang nyata terhadap tinggi tanaman padi sawah varietas IPB $3 \mathrm{~S}$ pada 3, 5, 6, dan $7 \mathrm{mst}$, tetapi perlakuan $6 \mathrm{~L} \mathrm{ha}^{-1}$ silika cair secara nyata dapat meningkatkan tinggi tanaman pada 4 mst. Hal tersebut diduga karena silika tidak memberikan pengaruh langsung terhadap pertumbuhan tanaman. 


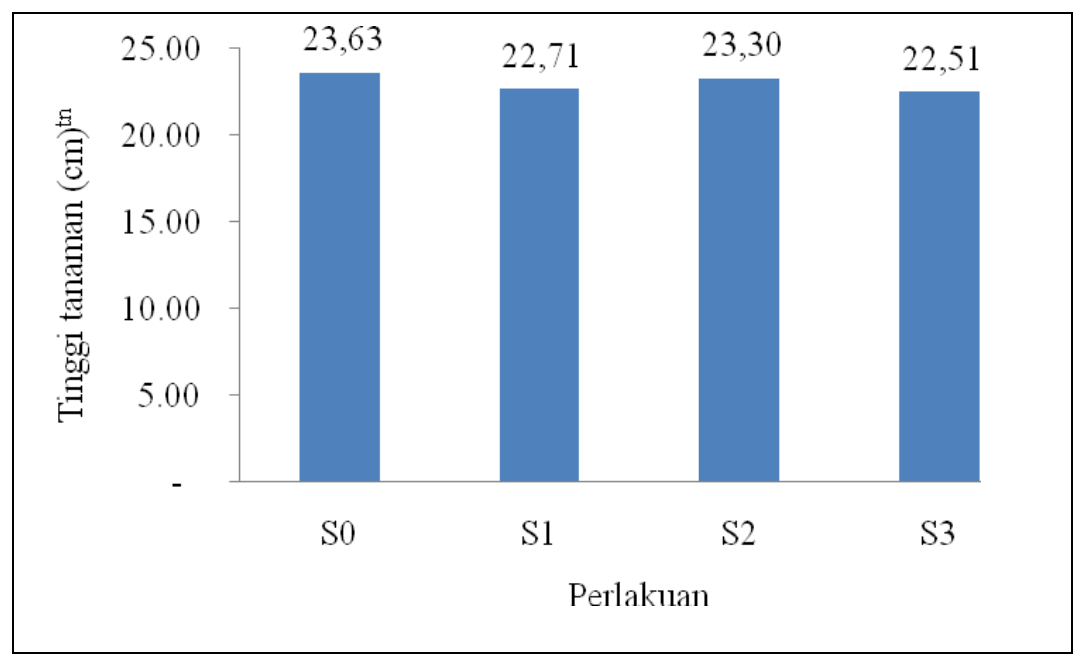

Gambar 1. Tinggi tanaman okra

Pemberian silika hanya dilakukan pada 14 mst dengan konsentrasi 1, 2, dan 3\%. Diduga serapan silika pada okra juga tidak meningkatkan tinggi tanaman. Penelitian Sari et al., (2015) pada tanaman kedelai menyatakan bahwa peningkatan konsentrasi silika sampai 400 ppm tidak berpengaruh pada pertumbuhan dan produksi benih berdasarkan semua variabel pengamatan. Diduga pemberian silika tidak berpengaruh pada pertumbuhan dan produksi kedelai karena silika bersifat imobil dan penggunaan varietas Tanggamus yang tidak responsif terhadap pemupukan. Penelitian Apriliyanto dan Hastuti (2012) pada tanaman cabai menyatakan bahwa penyerapan unsur hara oleh tanaman kemudian ditranslokasikan untuk peningkatan kualitas buah berupa pembentukan buah per satuannya yang semakin besar. Tingkat kerusakan tanaman oleh hama tidak hanya berpengaruh pada fase vegetatif tanaman saja, fase generatif juga dapat dipengaruhi oleh serapan hara tanaman.
Hasil analisis intensitas serangan hama kutu daun (Aphis sp.) dan ulat (famili Pyralidae) pada 28 hst menunjukkan tidak berbeda nyata, hanya intensitas serangan hama wereng daun (Empoasca sp.) yang menunjukkan berbeda nyata (Tabel 2.). Intensitas serangan hama kutu daun pada S0, S1, $\mathrm{S} 2$, dan S3 berturut-turut 1,43\%, 5,71\%, $9,29 \%$, dan $3,57 \%$. Intensitas serangan hama ulat pada S0, S1, S2, dan S3 berturut-turut $0,00 \%, 9,29 \%, 0,00 \%$, dan $4,64 \%$. Intensitas serangan hama wereng daun tertinggi pada perlakuan S0 yaitu $16,07 \%$, terendah pada perlakuan S1 dan $\mathrm{S} 2$ yaitu $0,00 \%$, sedangkan perlakuan S3 yaitu $8,57 \%$. Sugiyanta et al. (2018) menyatakan pupuk silika cair tidak efektif meningkatkan ketebalan kutikula tanaman padi. Perlakuan kontrol memiliki kutikula yang lebih tebal $(4768.6 \mathrm{~nm})$ dibandingkan seluruh perlakuan pupuk silika cair pada $6 \mathrm{mst}$ (3415.8-3821.2 nm), sedangkan pada 8, 9, dan 10 mst ketebalan kutikula perlakuan pupuk silika cair tidak berbeda nyata dengan perlakuan kontrol. 
Tabel 2. Intensitas serangan hama kutu daun, ulat, dan wereng daun tanaman okra

\begin{tabular}{cccc}
\hline Perlakuan & ${\text { Kutu daun }(\%)^{\mathrm{tn}}}$ & ${\text { Ulat }(\%)^{\mathrm{tn}}}$ & Wereng daun (\%) \\
\hline S0 & 1,43 & 0,00 & $16,07 \mathrm{a}$ \\
S1 & 5,71 & 9,29 & $0,00 \mathrm{~b}$ \\
S2 & 9,29 & 0,00 & $0,00 \mathrm{~b}$ \\
S3 & 3,57 & 4,64 & $8,57 \mathrm{ab}$ \\
\hline
\end{tabular}

Keterangan: Data dianalisis menggunakan Uji F, apabila berbeda nyata dilanjutkan dengan DMRT 5\%. tn = tidak nyata, angka yang diikuti huruf sama pada kolom yang sama menunukkan tidak berbeda nyata.

Kriteria kerusakan tanaman okra oleh kutu daun, ulat, dan wereng daun termasuk dalam kategori ringan. Kerusakan yang diamati pada bagian daun tanaman okra dan pada fase vegetatif tanaman. Perlakuan S1 dan S2 menunjukkan intensitas serangan wereng daun sebesar $0 \%$. Tetapi pada perlakuan S3 menunjukkan ada serangan wereng daun $8,57 \%$. Pada konsentrasi lebih tinggi serangan wereng daun mulai ada lagi.

Hasil analisis jumlah buah, bobot buah, dan bobot segar tanaman menunjukkan tidak berbeda nyata pada seluruh perlakuan (Tabel 2.). Jumlah buah okra pada S0, S1, S2, dan S3 berturut-turut 0,$90 ; 0,60 ; 0,70$; dan 0,30. Bobot buah okra pada S0, S1, S2, dan S3 berturut-turut 9,00 g; 6,50 g; 6,60; dan 3,40. Bobot segar tanaman okra pada S0, S1, S2, dan S3 berturut-turut $38,00 \mathrm{~g} ; 38,70 \mathrm{~g} ; 36,80 \mathrm{~g}$; dan $33,50 \mathrm{~g}$. Sari et al., (2015) pemberian silika tidak berpengaruh pada pertumbuhan dan produksi kedelai pada semua variabel pengamatan, baik terhadap pertumbuhan maupun produksi benih kedelai.

Tabel 3. Jumlah buah, bobot buah, dan bobot segar tanaman okra

\begin{tabular}{cccc}
\hline Perlakuan & Jumlah buah & Bobot buah $(\mathrm{g})$ & Bobot segar tanaman $(\mathrm{g})$ \\
\hline S0 & 0,90 & 9,00 & 38,00 \\
S1 & 0,60 & 6,50 & 38,70 \\
S2 & 0,70 & 6,60 & 36,80 \\
S3 & 0,30 & 3,40 & 33,50 \\
\hline
\end{tabular}

Lutfi et al., (2016), selain faktor kelembaban, tingginya intensitas serangan di awal pengamatan, diduga karena penyerapan pupuk $\mathrm{Si}$ Plus kedalam jaringan tanaman masih rendah, sehingga jaringan tanaman relatif lemah. Aplikasi pupuk Si Plus dengan metode infus dan semprot diduga memperkuat dinding jaringan epidermis dan jaringan pembuluh tanaman kakao, sehingga gejala serangan pada buah kakao dapat dihambat dan membuat intensitas serangan helopeltis menjadi rendah.

\section{SIMPULAN}

Pemberian silika pada tanaman okra belum mampu meningkatkan tinggi tanaman, jumlah buah, bobot buah, dan bobot segar tanaman. Intensitas serangan hama kutu daun pada S0, S1, S2, dan S3 berturut-turut $1,43 \%, 5,71 \%, 9,29 \%$, dan $3,57 \%$. Intensitas serangan hama ulat pada S0, S1, S2, dan S3 berturut-turut $0,00 \%, 9,29 \%, 0,00 \%$, dan $4,64 \%$. Intensitas serangan hama wereng daun tertinggi pada perlakuan So yaitu $16,07 \%$, terendah pada perlakuan S1 dan $\mathrm{S} 2$ yaitu $0,00 \%$, sedangkan perlakuan S3 yaitu $8,57 \%$. 


\section{DAFTAR PUSTAKA}

Adil, W.H., N. Sunarlim, dan I. Roostika. 2016. Pengaruh Tiga Jenis Pupuk Nitrogen terhadap Tanaman Sayuran. Biodiversitas. 7(1):77-80

Apriliyanto E., D. Hastuti. 2012. Pengaruh pemberian kompos gulma siam (Chromolaena odorata) terhadap populasi lalat buah pada tanaman cabai. Jur. Agroekotek. 4 (1) : 32-38.

Biswas, S., P. Panda, M. Hansda, K. Mandal. 2016. Screening of okra genotypes and preliminary studies on incidence of insect pests on okra (Abelmoschus esculentus L.). Journal of Agriculture and Technology. 3(1):55-57.

BPS Kab. Banjarnegara. 2017. Kecamatan Madukara dalam Angka 2017.

https://banjarnegarakab.bps.go.id [11 Maret 2018].

Dewi, A.Y., E.T.S. Putra, S. Trisnowati. 2014. Induksi ketahanan kekeringan delapan hibrida kelapa sawit (Elaeis guineensis Jacq.) dengan silika. Vegetalika. 3(3):1-13).

Fitriani, H.P., S. Haryanti. 2016. Pengaruh penggunaan pupuk nanosilika terhadap pertumbuhan tanaman tomat (Solanum lycopersicum) var. Bulat. Buletin Anatomi dan Fisiologi. 24 (1) : 3441.

Kristanto, B.A. 2018. Aplikasi Silika untuk Pengelolaan Kesuburan Tanah dan Peningkatan Produktivitas Padi Secara Berkelanjutan. Prosiding Seminar Nasional Pascasarjana Universitas Sebelas Maret (UNS) Surakarta "Optimalisasi Potensi Lingkungan untuk Mewujudkan Ketahanan dan Keamanan Pangan" Surakarta, 15 Agustus 2018.

Lutfi, M., J. Priyono, I. Muthahanas. 2016. pengaruh pemberian pupuk Si Plus terhadap intensitas serangan hama pengisap (Helopeltis antonii) dan penggerek buah kakao. Crop Agro. 9(2):118-121.
Nair, N., U. Giri, T. Bhattacharjee, B. Thangjam, N. Paul, M.R. Debnath. 2017. Biodiversity of insect pest complex infesting okra [Abelmoschus esculentus] in Tripura, N.E. India. Journal of Entomology and Zoology Studies. 5(5): 1968-1972.

Natawigena, H. 1993. Dasar-dasar Perlindungan Tanaman. Trigenda Karya. Bandung.

Nurmala, T ., A.Yuniarti, N. Syahfitri. 2016. Pengaruh berbagai dosis pupuk silika organik dan tingkat kekerasan biji terhadap pertumbuhan dan hasil tanaman hanjeli pulut (Coix lacryma jobi L) genotip 37. Jurnal Kultivasi. 15 (2) : 133-142.

Obeng-Ofori, D., J. Sackey. 2003. Field evaluation of non-synthetic insecticides for the management of insect pests of okra Abelmoschus esculentus (L.) Moench in Ghana. SINET: Ethiopian Journal of Science. 26(2):145-150.

Permana, D.P., A. Suprayogi, Y. Prasetyo. 2017. Identifikasi kesesuaian lahan untuk relokasi permukiman menggunakan sistem informasi geografis (Studi Kasus: Kabupaten Banjarnegara). Jurnal Geodesi Undip. 6(4):391-401.

Puteri, E.A., Y. Nurmiaty, Agustiansyah. 2014. Pengaruh aplikasi fosfor dan silika terhadap pertumbuhan dan hasil tanaman kedelai (Glycine max [L.] Merrill.). $J$. Agrotek Tropika. 2(2):241-245

Sari, E.P., Agustiansyah, Y. Nurmiaty. 2015. Pengaruh penyemprotan boron dan silika terhadap pertumbuhan dan produksi benih kedelai (Glicyne max [L.] Merrill). 36 Jurnal Agrotek Tropika 3(1):36-40, 2015 J. Agrotek Tropika. 3(1): 36 - 40.

Sugiyanta, I.M. Dharmika, D.S. Mulyani. 2018. Pemberian Pupuk Silika Cair untuk Meningkatkan Pertumbuhan, Hasil, dan Toleransi 
Kekeringan Padi Sawah. J. Agron.

Indonesia. 46(2):153-160.

Trisnaningsih, A. Nasution. 2015.

Ketahanan galur harapan padi

fungsional terhadap hama wereng coklat dan penyakit blas. Pros. Sem. Nas. Masy. Biodiv. Indon. 1(1): 162166. 